\title{
Growth of cell populations of the intralobular duct in the submandibular gland of the mouse during postnatal development
}

\section{Crescimento das populações de células dos ductos intralobulares na glândula submandibular do camundongo durante o desenvolvimento pós-natal}

Rumio Taga*

Luiz Carlos Pardini**

\begin{abstract}
The growth of cell populations of intercalated ducts (ID), striated ducts (SD) and convoluted granular tubules (CGT) of the submandibular gland of the mouse was analyzed, during the period of 14 to 84 days of postnatal life, by means of morphometric methods. The absolute number of cells in each type of duct was submitted to curve fitting by means of linear regression analysis, and the obtained equations were: $y=13.22+0.87 x$ for ID cells in the growth period of 14 to 84 days; $y=-18.82+3.69 x$ and $y=176.03-1.93 x$ for SD cells in the periods of growth and decay of cells, from 14 to 35 and 35 to 84 days, respectively; and $y=90.59+4.60 x$ for CGT cells in the growth period of 28 to 84 days. Based on these equations, the daily accumulation (growth rate) or loss (decaying rate) of cells in the period covered by each equation was calculated. Thus, the rate of growth of ID cells was $0.87 \times 10^{5}$ cells/day; the growth and decline rates of SD cells were $3.69 \times 10^{5}$ cells/day and $-1.93 \times 10^{5}$ cells/day, respectively; and the growth rate of CGT cells was $4.60 \times 10^{5}$ cells/day. The analysis of the accumulation or loss of cells and the balance of cell populations in the various types of ducts revealed that SD cells were transformed into CGT cells and that the growth of these cells' population also depends on the formation of new cells through proliferative activity, probably in the intercalated ducts.

DESCRIPTORS: Cells; Corpus striatum; Submandibular gland; Development.
\end{abstract}

\begin{abstract}
RESUMO: O crescimento de população de células dos ductos intercalares, ductos estriados e túbulos granulares convolutos de glândulas submandibulares do camundongo durante o período de 14 a 84 dias de vida pós-natal, foi avaliada por métodos morfométricos. Os dados de número absoluto de células em cada tipo de ducto foram submetidos a ajuste de curva por análise de regressão linear e as equações obtidas foram: $y=13,22+0,87 x$ para as células dos ductos intercalares no período de crescimento de 14 a 84 dias; $y=18,82+3,69 x$ e $y=176,03-1,93 x$ para as células dos ductos estriados nos períodos de crescimento e decaimento, respectivamente, de 14 a 35 e 35 a 84 dias; e $y=90,59+4,60 x$ para as células dos túbulos granulares convolutos no período de crescimento de 28 a 84 dias. À partir dessas equações, o acúmulo diário (velocidade de crescimento) ou a perda diária (velocidade de decaimento) de células em cada período, foram calculados. Assim, a velocidade de crescimento das células dos ductos intercalares foi $0,87 \times 10^{5}$ células/dia; as velocidades de crescimento e decaimento de células dos ductos estriados foram, respectivamente, $3,69 \times 10^{5}$ células/dia e $-1,93 \times 10^{5}$ células/dia; e a velocidade de crescimento das células dos túbulos convolutos foi $4,60 \times 10^{5}$ células/dia. Análise do acúmulo ou da perda de células e o balanço entre o crescimento das várias populações celulares ductais, mostraram numericamente que as células dos ductos estriados transformaram-se em células dos túbulos granulares convolutos e que o crescimento total na população dessas últimas células também depende da formação de novas células por atividade proliferativa, provavelmente nos ductos intercalares.
\end{abstract}

DESCRITORES: Células; Corpo estriado; Glândula submandibular; Desenvolvimento.

\section{INTRODUCTION}

It is known that the interlobular duct system of rodent submandibular gland is constituted essentially by the intercalated duct (ID), convoluted granular tubule (CGT) and striated duct (SD) $2.5,8,13,17,18,20,26,27$. Among these three structures, the CGT is the most conspicuous in histological sections due to its enor- mous total volume and to the fact that its cells are packed with serous secretory granules ${ }^{5,17}$.

In the mouse, these tubules are much more developed in males than in females, which characterizes a marked secondary sexual dimorphism ${ }^{2,3,10,14,16}$.

Electron microscopic studies both in rats ${ }^{6}$ and mice $^{8}$ revealed that their secretory cells are prima-

${ }^{*}$ Chairman, Department of Biological Sciences, School of Dentistry of Bauru; **Associate Professor, Department of Stomatology,

School of Dentistry of Ribeirão Preto - University of São Paulo. 
Taga R, Pardini LC. Growth of cell populations of the intralobular duct in the submandibular gland of the mouse during postnatal development. Pesqui Odontol Bras 2002;16(4):285-291.

rily differentiated from typical SD cells during the postnatal development. Studies on growth kinetics using H3-tymidine labeling have confirmed this event and suggested that IDs also participate in the supply of cells for CGTs ${ }^{4,7,22,23,29}$.

The objective of the present investigation was to establish the numerical relationship between the growth of these three types of duct cell populations during the postnatal development of the submandibular gland of the mouse, allowing to numerically characterize cell migration from one type of duct to another.

\section{MATERIALS AND METHODS}

Male mice (Mus musculus, Swiss strain) were obtained from a colony maintained in the Central Animal House, Dentistry School of Bauru, University of São Paulo, Brazil. The animals were assigned to groups of five subjects each, according to their age: $14,21,28,35,42,56$ and 84 days of postnatal life. The glands were collected always between 8:00 and 10:00 a.m. to avoid circadian variations. The animals were anaesthetized by means of inhalation of ethyl ether, and the body mass of each animal was determined using a Mettler P1000 scale. The submandibular glands of each animal were carefully dissected and rapidly removed, and its fresh mass was determined using a Mettler $\mathrm{H}-20$ precision scale. The glands were fixed in Helly's fluid for $3 \mathrm{~h}$, rinsed overnight in running water, dehydrated in ethyl alcohol, cleared in xylene and embedded in paraffin. Alternate 5-mm thick sections were obtained at intervals of $50 \mathrm{~mm}$ and stained by means of the Masson trichromic method.

\section{Determination of the processed gland volume (Vp)}

The processed gland volume (Vp) was calculated based on the fresh gland mass $(\mathrm{m})$, using the formula: $V p=m / \delta \times S f$, where $d$ is the average density of the gland and $S f$, the correction factor for the observed shrinkage. The density of the gland $(\delta)$ was determined in 20 submandibular glands from 10 young-adult mice by means of the method of Scherle, according to indications of Mandarim-de-Lacerda ${ }^{15}$. The shrinkage caused by the histological procedures was evaluated in 20 submandibular glands from other 10 young-adult animals by means of the method of Taga and $\mathrm{Sesso}^{24}$. The mean density $(\delta)$ obtained was $1.09 \mathrm{~g} / \mathrm{mm}^{3}$, with a coefficient of variation of $0.5 \%$, and the shrinkage factor (Sf) was 0.86 , with a coefficient of variation of $17.2 \%$.

\section{Morphometric determination of the absolute number of cells ( $\mathrm{Ni}$ )}

The counting of cells in each type of duct was carried out by means of a Zeiss microscope with an oil-immersion 100 X objective and an 8 X Zeiss Kpl eyepiece containing a Zeiss II integration grid with 10 parallel lines and 100 points distributed within a quadrangular area. The number of cell nuclei (ni) in each type of duct (i) and the crossings (ci) between the nuclear images and grid lines were counted in $\mathbf{5 0}$ histological fields per animal, which were selected by means of systematic sampling. The nuclei that falled on the forbidden line were not counted to avoid overestimation of data ${ }^{10}$. The absolute number of nuclei for each type of cell (ni) was calculated using the formula of Aherne ${ }^{1}$ :

$$
n i=\frac{2 n^{2} V p}{A\left(i^{2} d+2 t\right)},
$$

where: $\mathrm{A}=$ total examined area, $\mathrm{i}=\mathrm{ci} / \mathrm{ni}$, $\mathrm{d}=$ distance between the grid lines, and $\mathrm{t}=$ thickness of the histological section.

The number of 50 microscopical fields per animal was determined during the pilot work, by multiple $\div^{2}$ sample homogeneity test with a probability level ${ }^{25}$ of 0.05 .

It should be pointed out that in the 28-day-old group it was not possible to identify tubules in the paraffin-embedded sections - a very small number of secretory granules was observed, thus, in the counts, these cells were scored in SDs. In borderline instances, i.e., in segments of intralobular ducts containing a mixture of cells with a small number of secretory granules and cells apparently without them, cells were individually recognized and scored in CGTs and SDs, respectively.

During counting, the number of nuclei from cells of other structures, stroma and glandular parenchyma, was also recorded. Thus, the frequency of cells (\%) of each type of duct in the gland was calculated.

\section{Statistical analysis}

The morphometric data of each age group was compared with that of the other groups by means of ANOVA, using the Sigma Stat-Jadel Scientific Software for Windows version 1.0, with the level of significance set at 0.05 and 0.01 . According to recommendations of Russ and Dehoff ${ }^{19}$, the data on gland mass and absolute cell number in each 
Taga R, Pardini LC. Growth of cell populations of the intralobular duct in the submandibular gland of the mouse during postnatal development. Pesqui Odontol Bras 2002;16(4):285-291.

type of duct were submitted to curve fitting in function of the age by means of linear regression analysis using the Arcus Professional Statistical Analysis Software version 2.0XTc. The quality of curve fitting was assessed examining the value of the coefficient of determination $\left(r^{2}\right)$. Based on the equations, the daily gain in mass and the accumulation or loss of cells in each duct type were calculated.

\section{RESULTS}

The evolution of fresh gland mass from the $14^{\text {th }}$ to $84^{\text {th }}$ day of postnatal life is presented in Graph 1 .

Between 14 and 84 days of age, fresh gland mass increased significantly $(621 \%, \mathrm{p}<0.01)$, from $24.3 \mathrm{mg}$ on day 14 to $175.2 \mathrm{mg}$ on day 84 . The equation for gland mass increase was: $y=-0.61+2.27 x$ $\left(\mathrm{r}^{2}=0.94\right)$, and the calculated growth rate was $2.27 \mathrm{mg} /$ day.

The frequency of cells of each type of duct, estimated as a percentage of the total number of all types of cells, is presented in Graph 2.

Statistical "F" analysis after arcsin transformation of the original data revealed that: the frequency of ID cells decreased from $15.9 \%$ to $8.1 \%$ (p < 0.01), from day 14 to day 35; increased from $8.1 \%$ to $10.4 \%(\mathrm{p}<0.05)$ from day 35 to day 42 ; and remained stable thereafter ( $p>0.05)$; the frequency of SD cells increased from $14.4 \%$ to $26.9 \%$ ( $<<0.01$ ) from day 14 to day 28 and noticeably decreased from $26.9 \%$ to $2.1 \%$ (p < 0.01 ) from day 28 to day 84; CGT cells presented a frequency of $1.3 \%$ on day 28 , which continually increased up to $39.6 \%$ until the $84^{\text {th }}$ day of age $(\mathrm{p}<0.01)$. The evolution of the total number of cells of each type of duct is presented in Graph 3.

The analysis of data revealed that: the number of ID cells remained stable from day 14 to day 21 (p > 0.05). It presented a small increase of $25.3 \%$ from day 21 to day $28(\mathrm{p}<0.05)$, remained stable ( $p>0.05$ ) between day 28 and day 35 and increased $138.4 \%(\mathrm{p}<0.01)$ thereafter; the evolution of SD cells was biphasic, i.e., from day 14 to day 35 and from day 35 to day 84 . During the first phase they increased $307.5 \%(\mathrm{p}<0.01)-$ from $26.5 \times 10^{5}$ to $108.0 \times 10^{5}$ cells - and, in the second phase, they decreased $86.8 \%(\mathrm{p}<0.01)-$ from $108.0 \times 10^{5}$ to $14.3 \times 10^{5}$ cells. The number of CGT cells increased $8,123.5 \%(\mathrm{p}<0.01)$ from day 28 to day $84-3.4 \times 10^{5}$ to $279 \times 10^{5}$ cells.

The equations obtained from the regression analysis to mathematically express the evolution of cells of each type of duct are presented in Table 1. Although the number of intercalated duct cells exhibited a multiphasic growth pattern, it was also submitted to a single linear regression analysis in the entire period under study, with the objective of obtaining a mean value of daily cell accumulation for the period.

With these equations, the daily accumulation and the loss of cells were calculated. Whereby, the growth rate of ID cells during the period of 14 to 84 days was $0.87 \times 10^{5}$ cells/day; the growth and decline rates of SD cells for the periods of 14 to 35 and 35 to 84 days were $3.69 \times 10^{5}$ cells/day and $-1.93 \times 10^{5}$ cells/day, respectively; and the growth rate of CGT cells for the period of 28 to 84 days was $4.60 \times 10^{5}$ cells/day.

Table 2 presents the relationship between the absolute number of cells in each type of duct and the total number of duct cells in the submandibular glands of mice during the period of 28 to 84 days of postnatal life. In this table, the frequencies in parentheses represent the number of cells per type of duct as a percentage of the total number of duct cells, and the percentages of the last column represent the percental in-

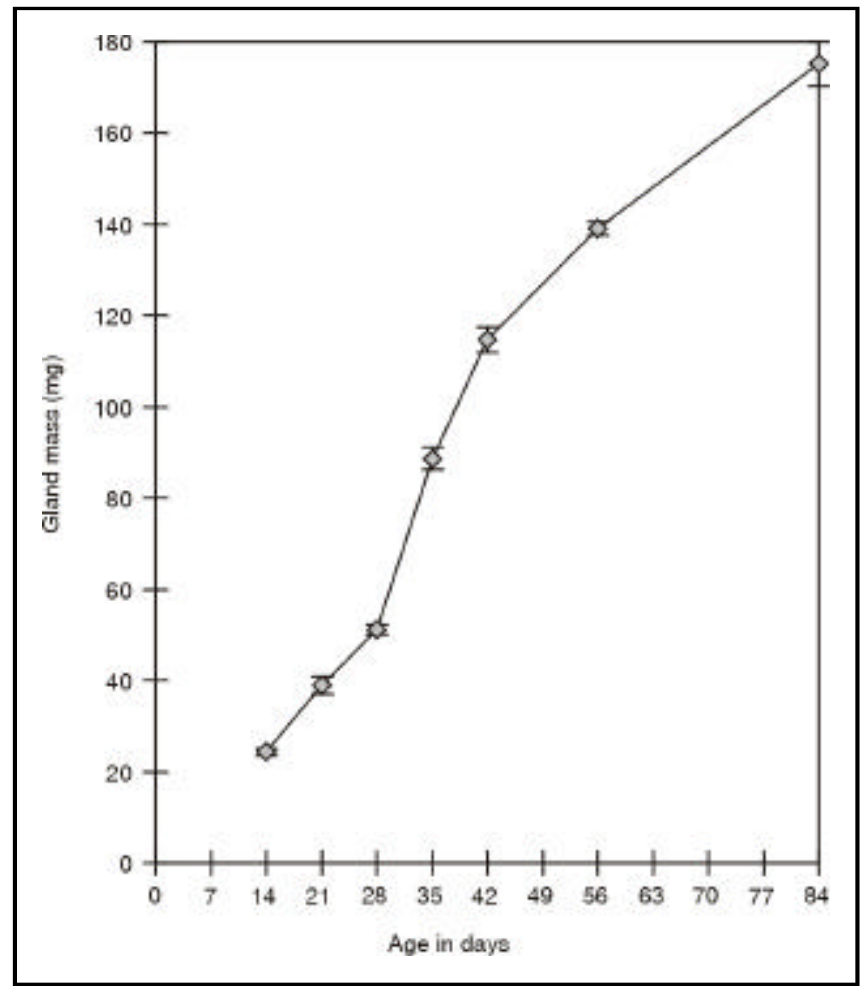

GRAPH 1 - Mass increase in the submandibular glands of mice during postnatal development (bars = standard error of mean). 
Taga R, Pardini LC. Growth of cell populations of the intralobular duct in the submandibular gland of the mouse during postnatal development. Pesqui Odontol Bras 2002;16(4):285-291.

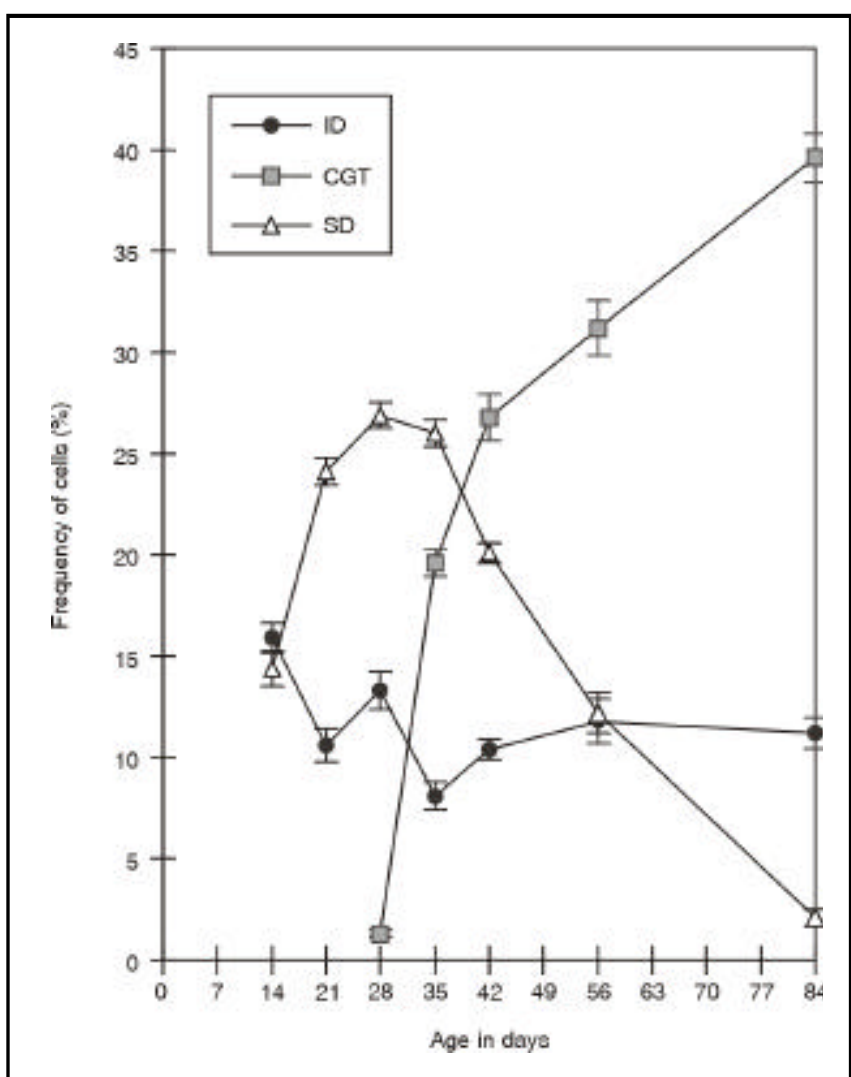

GRAPH 2 - Evolution of the frequency of each type of duct cell in the submandibular glands of mice during postnatal development (bars $=$ standard error of mean; ID = intercalated duct; $\mathrm{SD}=$ striated duct $; \mathrm{CGT}=$ convoluted granular tubule).

crease in the total number of duct cells during each stage of development.

Through the analysis of the data presented in the table, one can observe that: during the period from day 28 to day 35 of postnatal development, the total number of duct cells increased $81 \%$, i.e., $99.3 \times 10^{5}$ new cells were produced by mitotic activity $-75.5 \times 10^{5}$ cells were added to CGTs, and $25.3 \times 10^{5}$ cells, to SDs -; from day 35 to day 42 , the total number of cells increased $24 \%$, i.e., there were $54.2 \times 10^{5}$ new cells $-17.8 \times 10^{5}$ cells in IDs and $36.4 \times 10^{5}$ cells in CGTs. Since SDs lost $11.8 \times 10^{5}$ cells during the same period, and since these cells migrate to CGTs, the latter presented a total growth of $48.2 \times 10^{5}$ cells; during the subsequent period, from day 42 to day 56 , the total number of duct cells increased $16 \%$, i.e., $45.0 \times 10^{5}$ new cells were observed $-16.5 \times 10^{5}$ cells were added to IDs and $29.0 \times 10^{5}$ cells, to CGTs. Furthermore, CGTs received an additional $28.6 \times 10^{5}$ cells from SDs,

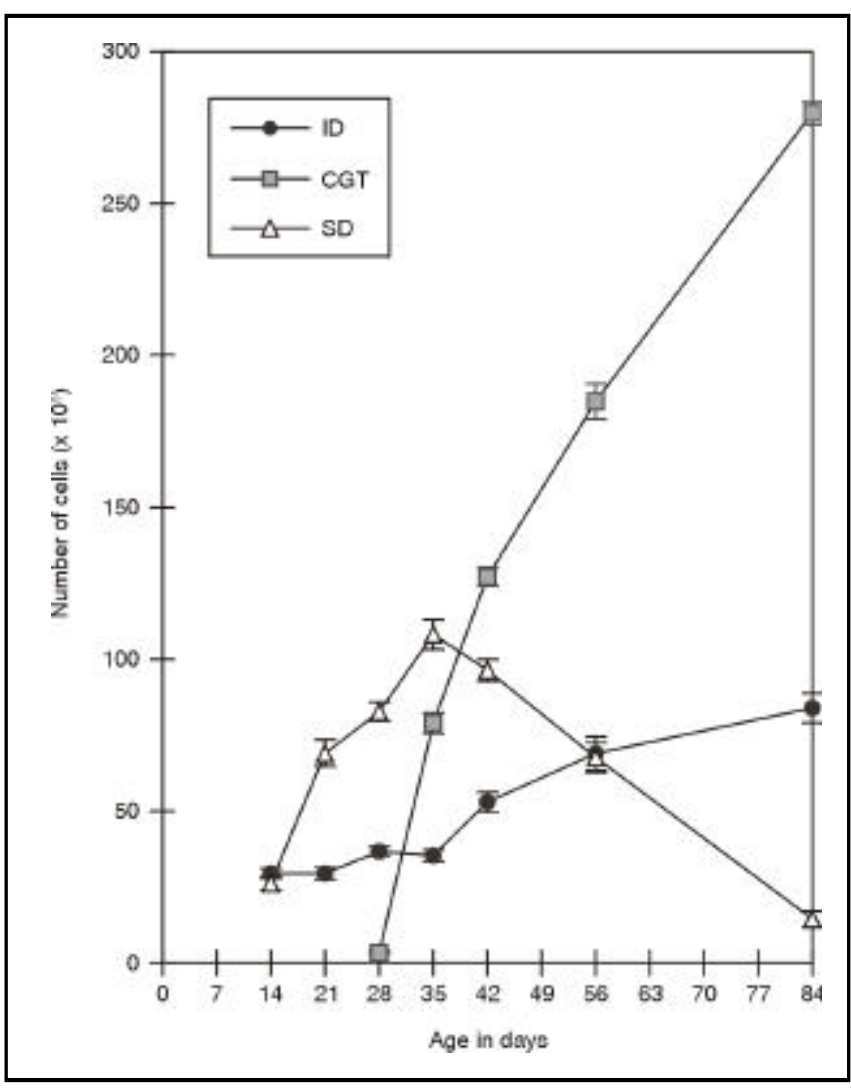

GRAPH 3 - Evolution of the number of each type of duct cell in the submandibular glands of mice during postnatal development (bars $=$ standard error of mean; ID = intercalated duct; $\mathrm{SD}=$ striated duct; $\mathrm{CGT}=$ convoluted granular tubule).

comprising a total of $57.6 \times 10^{5}$ additional cells in the period; and, finally, from day 56 to day 84 , the total number of new cells formed was $56.5 \times 10^{5}$ $14.9 \times 10^{5}$ cells were added to IDs and $41.6 \times 10^{5}$, to CGTs. Since the latter received more $53.3 \times 10^{5}$ cells previously accumulated in SDs, the total increase for the period was of $94.9 \times 10^{5}$ cells.

\section{DISCUSSION}

Despite the fact that studies on growth kinetics with H3-thymidine labeling, which assessed the developing and adult submandibular gland of rats and mice, have shown that the secretory cells of CGTs differentiate from typical SD cells and suggested that ID cells also participate in the supplement of cells for CGTs $^{4,7,22,23,29}$, there was lack of researches on the numeric characterization of these events.

Therefore, the objective of the present investigation was to determine, morphometrically, the pattern of cell accumulation in each intralobular type of duct of the submandibular gland of mice during 
Taga R, Pardini LC. Growth of cell populations of the intralobular duct in the submandibular gland of the mouse during postnatal development. Pesqui Odontol Bras 2002;16(4):285-291.

TABLE 1 - Linear regression equations for the growth of cell populations of the intercalated duct (ID), striated duct (SD) and convoluted granular tubule (CGT) in submandibular glands of mice $\left(\times 10^{5}\right)$.

\begin{tabular}{l|c|c|c}
\hline \hline \multicolumn{1}{c|}{ Cell type } & Analyzed period & Equation & Determination coefficient $\left(\mathrm{r}^{2}\right)$ \\
\hline ID cells & 14 to 84 days & $y=13.22+0.87 x$ & 0.94 \\
\hline \multirow{2}{*}{ SD cells } & 14 to 35 days & $y=-18.82+3.69 x$ & 0.96 \\
\cline { 2 - 4 } & 35 to 84 days & $y=176.03-1.93 x$ & 0.99 \\
\hline CGT cells & 28 to 84 days & $y=-90.59+4.60 x$ & 0.94 \\
\hline \hline
\end{tabular}

TABLE 2 - Relationship between the total number of cells in each type of duct and the total number of duct cells.

\begin{tabular}{c|c|c|c|c|c}
\hline \hline \multirow{2}{*}{$\begin{array}{c}\text { Period } \\
(\text { days })\end{array}$} & \multicolumn{3}{|c|}{ Cell number $\left(\times 10^{5}\right)$ and \%* } & Total number of duct cells & $\begin{array}{c}\text { Percentage of increase in the } \\
\text { total number of duct cells }\end{array}$ \\
\cline { 2 - 5 } & ID & SD & CGT & $\left.10^{5}\right)$ & - \\
\hline 28 & $36.7(29.9 \%)$ & $82.7(67.3 \%)$ & $3.4(2.8 \%)$ & 122.8 & $81 \%$ \\
\hline 35 & $35.2(15.8 \%)$ & $108.0(48.8 \%)$ & $78.9(35.4 \%)$ & 222.1 & $24 \%$ \\
\hline 42 & $53.0(19.2 \%)$ & $96.2(34.8 \%)$ & $127.1(46.0 \%)$ & 276.3 & $16 \%$ \\
\hline 56 & $69.0(21.5 \%)$ & $67.6(21.0 \%)$ & $184.7(57.5 \%)$ & 321.3 & $17 \%$ \\
\hline 84 & $83.9(22.2 \%)$ & $14.3(3.8 \%)$ & $279.6(74 \%)$ & 377.8 & - \\
\hline \hline
\end{tabular}

*Frequency in relation to the total number of duct cells. ID = intercalated duct; $\mathrm{SD}=$ striated duct; $\mathrm{CGT}=\mathrm{convoluted}$ granular tubule.

postnatal development, in order to numerically demonstrate cell migration from one duct to another.

The mass of the submandibular gland of the studied mice increased $621 \%$ from the $14^{\text {th }}$ to the $84^{\text {th }}$ day of age. During this growth in mass, the absolute number of ID cells presented a very small increase from day 14 to day 35 and a significant increase of $140 \%$ from day 35 to day 84 . The number of SD cells underwent a biphasic evolution, with a growth phase from day 14 to day 35 and a distinct decline phase from day 35 to day 84 . In the first phase, the number of cells increased 4.1 times and, in the second phase, it declined 7.6 times. In contrast, Srinivasan and Chang ${ }^{23}$ observed, for ID cells, an increase of approximately 337\% from day 14 to day 42; for SD cells, in the same growth and decline periods, those authors observed values much lower than those obtained in the present study.

As to the number of CGT cells, there was a marked increase of 82.2 times between day 28 and day 84 of postnatal development. It should be pointed out that Srinivassan and $\mathrm{Chang}^{23}$ detected, in the mouse strain studied in their research, not only a greater rate of differentiation of CGT secretory cells already from day 21 to day 28 , but also, a much greater contingent of these cells across all age ranges. Thus, they observed only a 4.14 times increase in the number of CGT cells from 28 to 84 days of age. The comparison between both reports revealed that this enormous difference was due to the very small number of CGT cells observed in our study, in 28-day-old mice.

Since the beginning of the study, the possibility of underestimation of the number of CGT cells on the 28-day-old group was considered, due to the difficulty in identifying immature CGT cells with a very small number of secretory granules in paraffin-embedded sections. New counts carried out in animals with 28 and 42 days of age, by means of the method of Weibel and Gomes ${ }^{32}$, using 0.5- $\mu$ m-thick plastic embedded sections, revealed results similar to those originally obtained by means of the Aherne's method for the 42-day-old group. However, for the 28-day-old group, the results were 20 to $30 \%$ greater. Therefore, in the original counts these cells had been scored in SDs. Nevertheless, even after correcting this underestimation, the differences remained extremely high.

Thereby, the differences mentioned above indicate that the gland of the mouse strain used in the present study exhibits a significantly greater contingent of SD cells and less ID and CGT cells during the analyzed developmental period. It should be noted that the values of body and gland mass, salivar amylase, biologically active factors, and even the histo-architecture of glands can vary between inbred 
Taga R, Pardini LC. Growth of cell populations of the intralobular duct in the submandibular gland of the mouse during postnatal development. Pesqui Odontol Bras 2002;16(4):285-291.

mouse strains, as well as between some hybrids $^{11,12,21,28}$. The analysis of daily accumulation and loss of cells revealed that, from day 28 to day 35, there was a clear predominance in the growth of CGT cell population, which accumulated 5.3 times more cells/day than IDs and 1.25 times more cells/day than SDs. Meanwhile, the SD cell population accumulated 4.2 times more cells/day than the IDs. Between 35 and 84 days, SDs lost $1.93 \times 10^{5}$ cells/day through the transformation into CGT cells. Since the latter type of duct accumulated $4.60 \times 10^{5}$ cells/day, a difference of $2.67 \times 10^{5}$ cells/day was lacking to complete this value.

The relationship between the number of cells accumulated in each type of duct and the total number of duct cells produced during the period of 28 to 84 days of age clearly revealed that the majority of the new cells formed by mitotic activity in any of the three types of ducts accumulates in CGTs, and, after day 35, CGTs receive an additional amount of cells which were previously accumulated in SDs.

In the analysis of the data reported by Srinivasan and $\mathrm{Chang}^{23}$, it was observed that, from 28 to 35 days, the labeling indices for ID cells were approximately 5.1 , i.e., these cells, presented the greatest proliferative activity during this period. For CGT cells, the values were 1.7 and 1.4 for each age group, respectively. On the other hand, for SD cells the values were the lowest observed in the period (approximately 0.5). Between 35 and 84 days, a decrease was observed in the labeling indices of all three types of duct cells. Thus, SDs indices became insignificant and those of CGTs and IDs, between day 42 and day 84 , decreased from 0.9 to 0.3 and 3.2 to 1.7 , respectively.

Assuming that the pattern of evolution of labeling indices for the various duct cells of the mouse strain used in the present study is similar to that

\section{REFERENCES}

1. Aherne W, Dunnil MS. Morphometry. London: Edward Arnold Ltd; 1982, p.60-70.

2. Assis GF, Sottovia Filho D, Stipp ACM, Taga R. Estudo morfométrico ultra-estrutural do dimorfismo sexual em células de ductos granulosos de glândulas submandibulares de camundongos. Rev Bras Biol 1994;54:21-9.

3. Caramia F. Ultrastructure of mouse submaxillary gland. Isexual differences. J Ultrastruct Res 1966;16:505-23.

4. Chai Y, Klauser DK, Denny PA, Denny PC. Proliferative and structural differences between male and female mouse submandibular glands. Anat Rec 1993;235:303-11. of the above-mentioned work, and that occasional differences are only related to the magnitude of the indices, it is possible to infer that, from day 28 to 35 , the new cells added to CGTs and SDs originate mostly from mitotic activity in IDs and, in small quantity, from CGTs and SDs themselves. Between day 35 and day 84, the new cells formed were added to IDs and, especially, to CGTs, where they were approximately half of the added cells and originated mainly from the mitotic activity of ID cells and, to a lesser extent, from mitosis within the own CGTs. The other half of the cells added to the CGTs came from SDs, where they were already accumulated during the previous period.

The analysis carried out in the present study numerically clarified cell migration between the three interlobular ducts in postnatal developing submandibular glands of mice, contributing to a better understanding of how the morphogenesis of the gland in question takes place.

\section{CONCLUSION}

The balance between the number of cells accumulated in the various types of intralobular ducts of the submandibular gland of mice during postnatal development numerically confirmed that striated duct cells transform into convoluted granular tubule cells. It also revealed that the growth of the latter cell population depends, substancially, on the production of new cells by means of mitotic activity, probably in intercalated ducts.

\section{ACKNOWLEDG MENTS}

This investigation was partially supported by FAPESP (84/1747-8 and 99/11597-9). The authors are indebted to Ms. Tania Mary Cestari for technical assistance, to Ms. Beonildes Teresinha Ruiz Correia for typing the manuscript, and to $\mathrm{CNPq}$ for research fellowship (301068/83-6/BM/FV).

5. Chrétien M. Action of testosterone on differentiation and secretory activity of a target organ: the submaxillary gland of the mouse. Int Rev Cytol 1977;50:333-96.

6. Cutler LS, Chaudhry AP. Cytodifferentiation of striated duct cells and secretory cells of the convoluted granular tubules of the submandibular gland. Am $J$ Anat 1975;143:201-18.

7. Denny PC, Chai Y, Klauser DK, Denny PA. Parenchymal cell proliferation and mechanisms for maintenance of granular duct and acinar cell populations in adult male mouse submandibular gland. Anat Rec 1993;235:475-85. 
Taga R, Pardini LC. Growth of cell populations of the intralobular duct in the submandibular gland of the mouse during postnatal development. Pesqui Odontol Bras 2002;16(4):285-291.

8. Gresik EW, MacRae EW. Postnatal development of the sexually dimorphic duct system and of amylase activity in the submandibular gland of mice. Cell Tiss Res 1975;157:411-22.

9. Gundersen HJG. Notes on the estimation of the numerical density of arbitrary profiles: the edge effect. J Microsc 1977;11:219-23.

10. Harvey H. Sexual dimorphism of submaxillary glands in mice in relation to reproductive maturity and sex hormones. Physiol Zool 1952;25:205-22.

11. Hilton F, Swigart J, Dickie M. Genetically determined differences in the amylase activity of mouse submaxillary glands. Proc Soc Exp Biol Med 1967;126:263-6.

12. Hjort JP. Genetic variation in quantity of mouse salivary. Hereditas 1978;89:142-52.

13. Jayasinghe NR, Cope GH, Jacob S. Morphometric studies on the development and sexual dimorphism of the submandibular gland of mouse. J Anat 1990;172:115-28.

14. Lacassagne A. Dimorphisme sexual de la glande sous-submaxillaire chez la souris. CR Soc Biol Fil 1940;133:180-1.

15. Mandarim-de-Lacerda CA. Manual de quantificação morfológica. Morfometria, Alometria e Estereologia. Monografia Científica: série morfologia. Rio de Janeiro: CEBIO; 1991:5-10.

16. Pardini LC, Taga R. Stereological study of the sexual dimorphism in mouse submandibular glands. Okajimas Folia Anat Jpn 1996;73:119-24.

17. Pinkstaff CA. The cytology of salivary glands. Int Rev Cytol 1980;63:141-261.

18. Raynaud J. Controle hormonal de la glande sous-maxillaire de la souris. Bull Biol Fr Belg 1960;94:399-523.

19. Russ JC, Dehoff RT. Statistical interpretation of data. In: Practical Stereology. New York: Plenum Press; 1999:130-58.
20. Sawada K, Noumura T. Effect of castration and sex steroid on sexually dimorphic development of the mouse submandibular gland. Acta Anat 1991;140:97-104.

21. Schneyer CA. Genetic control of amylase levels of mouse submaxillary glands. Proc Soc Exp Biol Med 1958;98:160-2.

22. Srinivasan P, Chang WWL. The development of the granular convoluted duct in the rat submandibular gland. Anat Rec 1975; 182:29-40.

23. Srinivasan P, Chang WWL. The postnatal development of the submandibular gland of the mouse. Cell Tiss Res 1979; 198:363-71.

24. Taga R, Sesso A. Avaliação do número de células de órgãos pela dosagem bioquímica de DNA em homogeneizados e por contagem direta através de métodos morfométricos. Ciên Cult 1978;30:1232-6.

25. Taga R, Sesso A, Pardini LC. Avaliação da homogeneidade da amostra em morfometria. Rev FOB 1998;6:57-60.

26. Tandler B, Nagato T, Toyoshima K, Phillips CJ. Comparative ultrastructure of intercalated ducts in major salivary glands: a review. Anat Rec 1998;252:64-91.

27. Tandler B, Gresik EW, Nagato T, Phillips CJ. Secretion by striated ducts of mammalian major salivary glands: review from an ultrastructural, functional and evolutionary perspective. Anat Rec 2001;264:121-45.

28. Tom-Moy M, Barka T. Epidermal growth factor in the submandibular glands of inbred mice. Am J Anat 1981;160:267-76.

29. Zajicek C, Yagil C, Michaeli Y. The streaming submandibular gland. Anat Rec 1985;213:150-8.

30. Weibel ER. Stereological methods. Practical methods for biological morphometry. Orlando: Academic Press; 1979. p.44-6. v.1. 